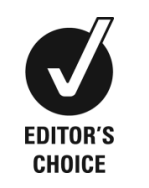
GS Medical College \& KEM Hospital, Mumbai, India

\section{Correspondence to} Professor Sunil Karande, karandesunil@yahoo.com

Accepted 8 August 2015

\title{
Consequences of low birth weight, maternal illiteracy and poor access to medical care in rural India: infantile iatrogenic Cushing syndrome
}

\author{
Sunil Karande
}

\section{SUMMARY}

Home delivery, low birth weight babies and maternal illiteracy among the poor in rural India are frequent. The rural poor prefer to seek healthcare from private providers, most of whom have no formal medical training and buy medicines from private pharmacies without a prescription owing to a weakly regulated environment. This report is of a 4-month-old baby from a remote village in northern India, who presented with exogenous Cushing syndrome. This baby was a full-term low birth weight home delivery. As the baby was not growing well, treatment was started at 1 month by a private doctor with betamethasone drops The mother on her own volition continued giving the betamethasone drops by buying the medicine over the counter from a private pharmacy. This case highlights the gaps in essential health services in rural India and the steps being taken to improve the situation.

\section{CASE PRESENTATION}

A 4-month-old predominantly breast fed infant presented with complaints of rapid weight gain for the past 2 months. The infant was a full-term low birth weight (LBW) (1.6 kg) delivery (intrauterine growth retardation). The delivery was conducted by the village dai (traditional birth attendant) at home. The mother had not attended any antenatal clinic during her pregnancy nor sought any postnatal care. The infant had not been immunised.

For complaints of 'not growing well' at the age of 1 month the private village doctor had started treatment with $1 \mathrm{~mL}$ betamethasone drops (1 $\mathrm{mL}=0.5 \mathrm{mg}$ ) twice a day as a 'general tonic'. The mother did not have any prescription from the private village doctor but she had a betamethasone drops bottle with her. On her own volition the mother had continued giving these drops. On inquiry, she stated that she would buy the next bottle from a local private 'medicine shop' by just showing the earlier empty bottle.

The patient is the first born. His 18-year-old mother is a homemaker and his 22-year-old father is a landless farmer. The mother is illiterate and the father has received only pre-primary education. The father is the sole earner and works as a daily farm helper earning about 3000 Indian rupees a month $(£ 30)$. The family lives in a small hut made of mud walls and thatched roof in a remote village in a northern state of India.

On examination, the infant had typical features of iatrogenic Cushing syndrome (ICS)—namely, 'moon face' with prominent boggy cheeks and a plethoric, flushed appearance (figure 1). There was generalised obesity and the back and trunk showed several folds due to accumulation of subcutaneous fat (figure 2). The infant was $60 \mathrm{~cm}$ in length (25th-50th centile) and weight was $5.37 \mathrm{~kg}$ (25 th50th centile) according to the standard WHO growth charts. Blood pressure was $114 / 82 \mathrm{~mm} \mathrm{Hg}$ ( $>95$ th centile). Fundi were normal and there were no cataracts. Skin did not show striae.

On investigation, a complete blood count, blood sugar and serum calcium were normal. The child's morning serum cortisol level was $0.8 \mu \mathrm{g} / \mathrm{dL}$ (normal $2.8-23 \mu \mathrm{g} / \mathrm{dL}$ ) and adrenocorticotrophic hormone $<5 \mathrm{pg} / \mathrm{mL}$ (normal $10-50 \mathrm{pg} / \mathrm{mL}$ ); both very low, diagnostic of exogenous ('iatrogenic') Cushing syndrome. Betamethasone was gradually tapered over the next 2 weeks. Oral propranolol at $1 \mathrm{mg} / \mathrm{kg} /$ day in three divided doses was started to treat the hypertension. The blood pressure normalised within the first 2 weeks of hospital stay. Subsequently, propranolol was tapered over the next week and stopped. After 3 weeks' hospital stay

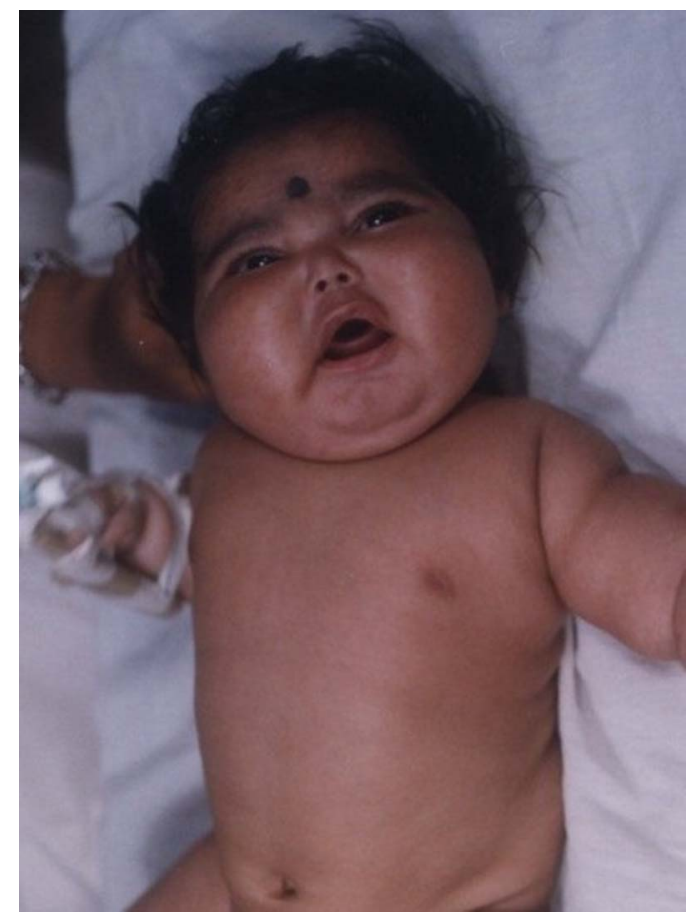

Figure 1 Moon-face, boggy cheeks with plethoric flushed appearance and generalised increase in subcutaneous fat. 


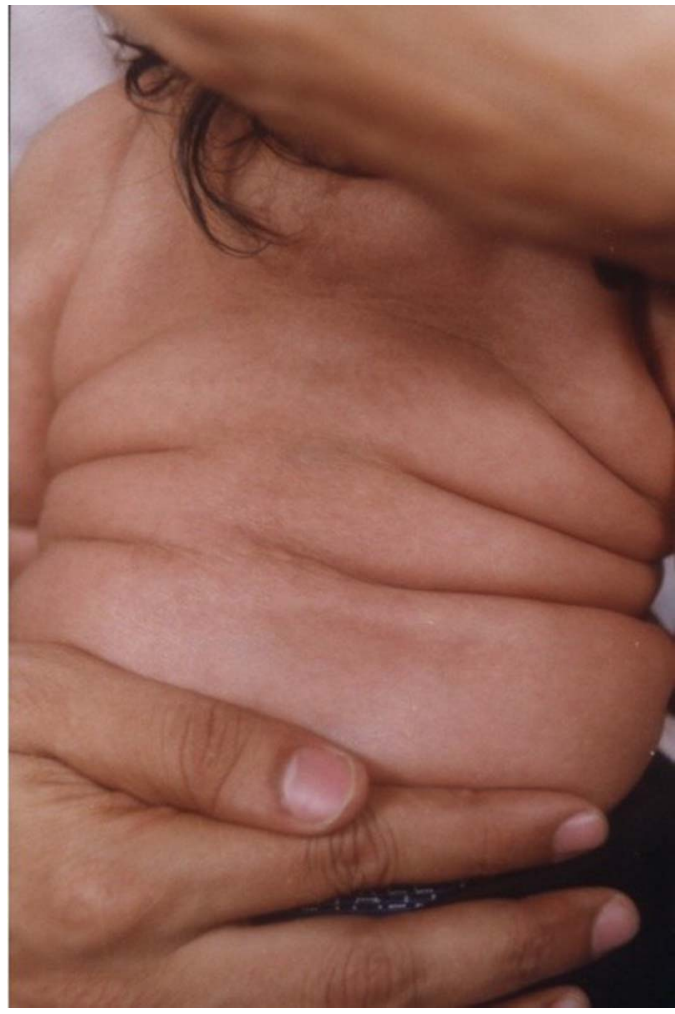

Figure 2 Infant's back showing multiple skin folds due to accumulation of subcutaneous fat.

the infant was discharged. On follow-up after a month, the infant's obesity had reduced (weight $4.97 \mathrm{~kg}$ ) and the plethoric, flushed facial appearance and boggy cheeks had also regressed.

\section{GLOBAL HEALTH PROBLEM LIST}

- High prevalence of home delivery and LBW babies amongst the poor in rural India.

- Poor access to medical care, low socioeconomic status (SES) of families and maternal illiteracy directly affect healthseeking behaviours.

- Most village doctors in rural India are unqualified.

- Unregulated drug prescription and dispensing practices are endemic in rural India and can result in a life-threatening condition such as ICS.

\section{GLOBAL HEALTH PROBLEM ANALYSIS}

India is the second largest populated country in the world with a population of 1.2 billion, of which almost $70 \%$ (840 million) live in rural areas across 640867 villages. ${ }^{1}$ Poverty is a chronic condition for almost 30\% (252 million) of India's rural population. $^{2}$ In India the literacy rate in 2011 was $74.04 \%$ as compared with $64.83 \%$ in 2001 (an increase of 9.21\%); with male literacy rate $82.14 \%$ and female literacy rate $65.46 \%$. $^{3}$ The improvement in literacy rate in rural areas is twice that in urban areas. The rural-urban literacy gap, which was $21.2 \%$ in 2001 , had reduced to $16.1 \%$ in 2011. Improvement in female literacy is greater than in men in both rural and urban areas. ${ }^{4}$ The gender gap in literacy had come down from $24.6 \%$ in 2001 to $19.8 \%$ in 2011 in rural areas and from $13.4 \%$ in 2001 to $9.8 \%$ in 2011 in urban areas; clearly indicating that the gender gap in literacy is shrinking in both urban and rural India ${ }^{4}$ However, high levels of illiteracy (overall 31.1\%, men 21.4\%, women
41.2\%) and limited access to healthcare continue to be common problems among poor Indian rural people. ${ }^{2} 45$

LBW ( $<2500 \mathrm{~g}$ regardless of gestational age), which is often associated with preterm birth, is an important predictor of infant death within 28 days of birth. ${ }^{4-6}$ It is estimated that globally, out of 139 million live births, more than 20 million LBW babies are born each year-over 95\% of them in developing countries, mainly of South Asia and sub-Saharan Africa. ${ }^{4}$ It is also estimated that in developing countries, LBW infants have much higher rates of morbidity and are approximately 13 times more likely to die than their normal birth weight counterparts. $^{6} 7$ LBW occurs in about $20-30 \%$ of all live births in India. ${ }^{8}$ Maternal undernutrition (before and during pregnancy), low SES, poor education and lack of antenatal care are the most important risk factors for $\mathrm{LBW}^{4}{ }^{5} 9{ }^{10} \mathrm{~A}$ recent report indicates that two-fifths of pregnant women in India are underweight. ${ }^{11}$ Only $42 \%$ gain about $7 \mathrm{~kg}$ during pregnancy ( $12 \mathrm{~kg}$ being the recommended weight gain). ${ }^{12}$ In rural northern India, until a decade and a half ago, nearly $70 \%$ of women in their last pregnancy did not receive any antenatal check-up. ${ }^{13}$ In rural India, about $75 \%$ of deliveries in poor families still take place at home; a phenomenon common to other developing countries. $^{14} 15$ Of these, only $5.7 \%$ births are attended by a skilled birth attendant-namely, a trained health worker staff nurse, lady health visitor and auxiliary nurse midwife (ANM), who can handle common obstetric and neonatal emergencies and detect and recognise when a situation reaches a point beyond his/her capability, and refer the woman/newborn to an appropriate facility without delay. ${ }^{16}$

India has implemented the Alma Ata declaration of 'Comprehensive Primary Health Care' since $1978 .{ }^{17}$ The public health system in rural India consists of three tiers: subcentres (SCs), primary health centres (PHCs) and community health centres (CHCs) based on standard population norms. ${ }^{17}$ For every 5000 population there should be a SC, which should be staffed by one male and at least one female health worker/ANM and is the first contact point for primary care. For every 30000 population there should be a PHC, which should be staffed by a qualified allopathic doctor and other paramedical staff. A PHC represents the second level of the rural public healthcare system and it serves as referral centre for six SCs. For every 100000 population there should be a CHC, which is a 30-bed hospital and should be staffed by four specialist doctors; it serves as referral centre for four PHCs. ${ }^{17}$ The government of India up to 2011 had been able to construct 148124 SCs, 23887 PHCs and 4809 CHCs. $^{17}$

Unfortunately, the rural public health system of India has not been effective in providing healthcare for a majority of rural India. ${ }^{14}{ }^{17}$ Several thousands of posts for doctors and surgeons remain vacant. ${ }^{1417}$ About $13 \%$ of all medical posts and $38 \%$ of specialist posts are vacant in PHCs in rural areas. ${ }^{18}$ Poor quality of care, such as overcrowding, lack of confidentiality, lack of empathy, poor staff behaviour, long waiting times, long distance from home, and lack of proper discussion and counselling from healthcare providers are significant reasons for the loss of trust by pregnant rural women in the public health delivery systems. ${ }^{19}$

Consequently, most rural people seek the first level of healthcare close to home, and pay themselves to seek care from private healthcare providers. ${ }^{20}$ For treatment of newborn danger signs, kamshakti (LBW), private healthcare providers, are preferred as they are perceived as specialists of their subject. ${ }^{21}$

Recent reviews of studies from low- and middle-income countries reported that private healthcare providers may be more responsive, familiar with patients' belief systems and patient- 
centred than public healthcare providers. ${ }^{22} 23$ MBBS doctors in private practice are a rarity in rural India, constituting only $5.6 \%$ of private healthcare providers. ${ }^{24}$ Private non-degree allopathic practitioners (NDAPs) are the de facto first-level access in most cases; some do not have any medical qualification ('unqualified practitioners'), whereas others are AYUSH doctors - that is, they hold degrees from traditional Indian systems of medicine (Ayurveda, Yoga and Naturopathy, Unani, Siddha and Homeopathy). Most private NDAPs prescribe allopathic drugs. $^{25}$ A large majority of NDAPs (92.7\%) dispense medicines directly to patients seen by them. ${ }^{24}$ Some NDAPs also provide 'doorstep' services, travelling from house to house and village to village on their daily service delivery rounds. ${ }^{20}$

Private AYUSH healthcare providers have been reported to prescribe steroids to $9.6 \%$ of their patients, statistically indistinguishable from $7.8 \%$ by private MBBS doctors. ${ }^{26}$ Interpersonal communication between private healthcare providers (both MBBS and NDAPs) and clients during a consultation has been reported to be poor in more than $80 \%$ of cases in rural India. ${ }^{27}$ Raveenthiran reported that ICS is being increasingly diagnosed in rural southern India as both private MBBS and NDAPs doctors dispense betamethasone drops to make infants rapidly chubby, which impresses their illiterate mothers, so much so, that some of them use betamethasone as a household selfmedication and even recommend its use to neighbours. ${ }^{28}$ ICS, as in the present case, is a potentially fatal condition due to thromboembolic or hypertensive complications or inability of the body to respond to bacterial infection. ${ }^{29}{ }^{30} \mathrm{~A}$ child who has developed ICS should be considered to have functional suppression of the hypothalamic-pituitary-adrenal axis, and corticosteroids should be gradually tapered to prevent the risk of adrenal crisis. $^{30}$

In rural India and also in several other low- and middle-income countries private pharmacies are poorly regulated. ${ }^{31}$ Also, in gross violation of the law, most private pharmacies do not have a pharmacist. ${ }^{31}$ Nearly $50-60 \%$ of all clients purchase medicines without a prescription. ${ }^{32} 33$

In this case, the low SES and lack of antenatal care (ANC) led to the mother giving birth to a LBW baby. The mother was illiterate and unaware of ANC services and how to care for her baby and had no one to advise her. The family's trust in the private village doctor (whose qualifications remain unknown) led them to consult him owing to their perception that their child was not growing well. The faulty practice of dispensing betamethasone coupled with the mother's self-medication and easy access to the drug without any prescription led to development of ICS.

In 2005, the government of India undertook the nationwide National Rural Health Mission (NRHM) to improve, in a phased manner, functioning of the rural healthcare delivery system by setting up new SCs, PHCs and CHCs where required and appointing doctors/nurses/ANMs to the vacant posts and ensuring a regular supply of drugs. ${ }^{14} 34$ A number of specific objectives are being implemented (related to the present case).

(1) Providing every village with a skilled birth attendant and a trained female community health activist-accredited social health activist (ASHA) ${ }^{14}{ }^{34}$ Each ASHA must be a woman resident in the village, aged 25-45 years and literate (with formal education up to class eight). The ASHA will be the flag bearer of the NRHM by being the first contact point for any health-related demand and will provide a bridge between community and first level government health sector (SC/PHC). ${ }^{34}$

(2) Each ASHA will also operate the national conditional cash transfer scheme, Janani Suraksha Yojana (JSY), an intervention for safe motherhood, which provides a cash incentive of 500 Indian rupees $(£ 5.09)$ for giving birth in an SC/PHC. ${ }^{35}$ The scheme also offers free antenatal care during pregnancy, and institutional care during delivery and the immediate post-partum period in a public health centre. ${ }^{35}$ Since introduction of the JSY, antenatal registration, institutional deliveries and postnatal check-ups have increased. $^{36}$

(3) For a home delivery the ASHA will be present at birth for the care of the newborn and even make repeated postnatal visits to care for the mother and baby-namely, assistance with breastfeeding, thermal care and danger sign recognition. ${ }^{34}$ For an LBW delivery, the ASHA teaches the mother the "kangaroo mother care' method-that is, constant nursing of the baby skin to skin on the mother's chest to provide optimal thermal care and also prevent lactational failure, thus helping to ensure exclusive breast feeding. ${ }^{37}$ Kangaroo mother care has been reported to improve growth and reduce morbidities in LBW infants born at home in remote Indian villages. ${ }^{38-40}$ The ASHA's role of providing home-based neonatal care has now been incorporated into the Integrated Management of Neonatal and Childhood Illness (IMNCI), a national programme started in India in 2003. ${ }^{41}$ The IMNCI programme has resulted in a higher prevalence of optimal newborn care practices, including starting breast feeding within an hour of birth, not giving prelacteal feeds, exclusive breast feeding, delayed bathing and applying nothing or gentian violet paint to the umbilical cord, resulting in substantial improvement in infant survival and in neonatal survival in those born at home. ${ }^{41}$

(4) To increase the presence of clinicians in rural communities, several states in India have staffed PHCs with AYUSH doctors and given them permission to dispense basic allopathic medicines in selected areas. Since 2011, the government of India has proposed creating a parallel stream of community health practitioners-namely, rural medical assistants (RMAs) who would be deployed in PHCs in rural areas that have an acute shortage of graduate MBBS doctors. ${ }^{42}$ These RMAs would qualify after passing a basic 3-year medical training course. $^{42}$ The system of deploying RMAs ('bare foot doctors') in rural areas has been shown to be effective in improving healthcare in 47 sub-Saharan Africa countries and China. ${ }^{43}$ However, the Indian Medical Association has strongly criticised this proposal and called it retrograde, dangerous and unethical. ${ }^{18}$ Also, some Indian states have incorporated the existing unqualified practitioners and after a period of training accredited them as rural health practitioners to serve at SCs. ${ }^{44}$

(5) To educate, via voice mails, rural women about antenatal care, maternal nutrition, the need for iron and folic acid tablet consumption and newborn care, the government of India has started introducing in phases the 'Mother and Child Tracking System' (MCTS) within the NRHM. ${ }^{45}$ Since India has 877 million mobile phone subscribers, the second largest subscriber base in the world and that too with one of the lowest mobile call tariffs, the MCTS at an economical cost will be able to reach even illiterate women in rural areas. ${ }^{45}$

(6) Since 1975 the government of India has begun implementing a welfare programme-namely, the Integrated Child Development Services (ICDS) scheme, whose beneficiaries include children aged $<6$ years, pregnant and lactating mothers, and other women in the age group $15-44$ years. ${ }^{46}$ Services provided includes supplementary nutrition, immunisation, health check-up, referral services, nutrition and health education, and pre-school education. These services are provided from Anganwadi centres (community child development centres) established mainly in rural areas. ${ }^{46}$ India runs the world's largest 
ICDS scheme with over 40000 centres nationwide, covering over 4.8 million expectant and nursing mothers and over 23 million children aged $<6$ years. ${ }^{46}$

(7) Since 2008, the government of India has begun implementing the National Program of Mid-Day Meal in Schools (NP-MDMS) across the country. ${ }^{47}$ India's NP-MDMS is the largest nutritional programme for school children in the world, covering 104.4 million children in 1.2 million schools across the country. ${ }^{47}$ This programme has resulted in school children receiving cooked meals that supply at least one-third of the recommended calories and half of the proteins to every school child. ${ }^{47}$ Alleviation of classroom hunger is also aimed at improving academic achievement in undernourished children. The NP-MDMS has resulted in an increase in enrolment, attendance and retention of children in primary schools. It has also helped to enhance gender equality as more parents are now sending their daughters to school. ${ }^{47}$

(8) Since 2010, the government of India has introduced the Right of Children to Free and Compulsory Education Act, 2009 (RTE Act) which makes quality education free and compulsory for all children of India in the 6-14 years age group. ${ }^{48}$ Once every child receives 8 years of quality elementary education the scourge of illiteracy will be erased. Education is one of the most important aspects of human resource development. Education of female children has been shown to be the key factor for improving quality of maternal healthcare and access to, and use of, ANC services. 949

It is envisaged that effective implementation of the government of India's NRHM, IMNCI, ICDS, NP-MDMS and RTE programmes will result in all Indian mothers and children, even those in remote villages as in the present case, having access to quality healthcare services and being well nourished and literate. This will improve the use of ANC services, improve maternal weight gain during pregnancy, increase institutional deliveries, reduce the birth of LBW babies and lead to better care of LBW babies. Effective regulation of drug prescription and dispensing practices will help to prevent adverse events such as ICS, as in the present case.

Learning points

- Improving access to antenatal care would help to reduce the high prevalence of low birth weight (LBW) babies in rural India.

- Home-based management of LBW babies in remote villages is feasible and needs to be introduced throughout rural India.

- Effective implementation of the National Rural Health Mission will help to improve access to quality health services in rural India.

- Effective implementation of the Right to Education Act will improve literacy rates among rural children, especially girls, and in the long run improve health-seeking behaviours of future mothers.

- Strict control and monitoring of drug prescription and dispensing practices will help to prevent adverse events such as iatrogenic Cushing syndrome.

Acknowledgements The author thanks the Dean, Seth GS Medical College \& KEM Hospital, for granting permission to publish this case report; and the patient's father for giving me written informed consent to publish photographs and details of his child's illness.
Competing interests None declared.

\section{Patient consent Obtained.}

Provenance and peer review Not commissioned; externally peer reviewed.

\section{REFERENCES}

1 Provisional Population Totals. Rural-urban distribution. Figures at a glance, India. (Online) 2012. Office of the Registrar General \& Census Commissioner, Government of India. http://www.censusindia.gov.in/2011-prov-results/paper2/data_files/india/ paper2_at_a_glance.pdf (accessed 10 May 2015).

2 Rural Poverty Portal. Rural poverty in India. http://www.ruralpovertyportal.org/ country/home/tags/india (accessed 10 May 2015).

3 Status of Literacy. Population census of India, 2011. http://censusindia.gov.in/ 2011-prov-results/data_files/india/Final_PPT_2011_chapter6.pdf (accessed 6 July 2015).

4 Rural Urban Distribution of Population. Census of India, 2011. http://censusindia. gov.in/2011-prov-results/paper2/data_files/india/Rural_Urban_2011.pdf (accessed 6 Jul 2015).

5 Bhutta ZA. The ignominy of low birth weight in South Asia. Indian Pediatr 2012:49:15-16.

6 Black RE, Allen LH, Bhutta ZA, et al. Maternal and child undernutrition: global and regional exposures and health consequences. Lancet 2008;371:243-60.

7 Yasmin S, Osrin D, Paul E, et al. Neonatal mortality of low-birth-weight infants in Bangladesh. Bull World Health Organ 2001;79:608-14.

8 Bharati P, Pal M, Bandyopadhyay M, et al. Prevalence and causes of low birth weight in India. Malays J Nutr 2011;17:301-13.

9 Muthayya S. Maternal nutrition \& low birth weight-what is really important? Indian J Med Res 2009;130:600-8.

10 Mumbare SS, Maindarkar G, Darade R, et al. Maternal risk factors associated with term low birth weight neonates: a matched-pair case control study. Indian Pediatr 2012;49:25-8.

11 Kmietowicz Z. Two fifths of pregnant women in India are underweight. BMJ 2015:350:h1241.

12 Coffey D. Prepregnancy body mass and weight gain during pregnancy in India and sub-Saharan Africa. Proc Natl Acad Sci USA 2015;112:3302-7.

13 Pallikadavath S, Foss M, Stones RW. Antenatal care: provision and inequality in rural north India. Soc Sci Med 2004;59:1147-58.

14 Qadeer I. The challenge of building rural health services. Indian J Med Res 2011;134;591-3.

15 Montagu D, Yamey G, Visconti A, et al. Where do poor women in developing countries give birth? A multi-country analysis of demographic and health survey data. PLOS ONE 2011;6:e17155.

16 Guidelines for Antenatal Care and Skilled Attendance at Birth by ANMs/LHVs/SNs 2010. Maternal Health Division, Ministry of Health \& Family Welfare, Government of India. http://www.nhp.gov.in/sites/default/files/anm_guidelines.pdf (accessed 10 May 2015).

17 Garg S, Singh R, Grover M. India's health workforce: current status and the way forward. Natl Med J India 2012;25:111-13.

18 Mudur G. Doctors criticise proposal for community practitioners in rural India. BMJ 2007;334:12

19 Das A, Sarkar M. Pregnancy-related health information-seeking behaviors among rural pregnant women in India: validating the Wilson model in the Indian context. Yale J Biol Med 2014;87:251-62.

20 Gautham M, Binnendijk E, Koren R, et al. 'First we go to the small doctor': first contact for curative health care sought by rural communities in Andhra Pradesh \& Orissa, India. Indian J Med Res 2011;134:627-38.

21 Dongre AR, Deshmukh PR, Garg BS. Childhood morbidity, household practices and health care seeking for sick children in a tribal district of Maharashtra, India. Indian J Med Sci 2010;64:7-16.

22 Berendes $\mathrm{S}$, Heywood $\mathrm{P}$, Oliver $\mathrm{S}$, et al. Quality of private and public ambulatory health care in low and middle income countries: systematic review of comparative studies. PLoS Med 2011;8:e1000433.

23 Willis JR, Kumar V, Mohanty S, et al. Utilization and perceptions of neonatal healthcare providers in rural Uttar Pradesh, India. Int I Qual Health Care 2011;23:487-94.

24 Kumar R, Jaiswal V, Tripathi $S$, et al. Inequity in health care delivery in India: the problem of rural medical practitioners. Health Care Anal 2007;15:223-33.

25 May C, Roth K, Panda P. Non-degree allopathic practitioners as first contact points for acute illness episodes: insights from a qualitative study in rural northern India. BMC Health Serv Res 2014;14:182.

26 Das J, Holla A, Das V, et al. In urban and rural India, a standardized patient study showed low levels of provider training and huge quality gaps. Health Aff (Millwood) 2012;31:2774-84.

27 Ganguly E, Deshmukh P, Garg B. Quality assessment of private practitioners in rural Wardha, Maharashtra. Indian J Community Med 2008:33:35-7.

28 Raveenthiran V. Misuse of corticosteroids in infants of rural Tamilnadu. Indian Pediatr 2008;45:1008. 
29 Tempark T, Phatarakijnirund V, Chatproedprai S, et al. Exogenous Cushing's syndrome due to topical corticosteroid application: case report and review literature. Endocrine 2010;38:328-34.

30 Hopkins RL, Leinung MC. Exogenous Cushing's syndrome and glucocorticoid withdrawal. Endocrinol Metab Clin North Am 2005;34:371-84.

31 Smith $F$. The quality of private pharmacy services in low and middle income countries: a systematic review. Pharm World Sci 2009;31:351-61.

32 Basak SC, Sathyanarayana D. Evaluating medicines dispensing patterns at private community pharmacies in Tamilnadu, India. South Med Rev 2010;3:27-31.

33 Sabde YD, Diwan V, Saraf VS, et al. Mapping private pharmacies and their characteristics in Ujjain district, central India. BMC Health Serv Res 2011;11:351.

34 Meeting People's Health Needs in Rural Areas. National Rural Health Mission. Framework for Implementation 2005-2012. Ministry of Health and Family Welfare, Government of India. http://nrhm.gov.in/images/pdf/about-nrhm/ nrhm-framework-implementation/nrhm-framework-latest.pdf (accessed 10 May 2015).

35 About Accredited Social Health Activist (ASHA). National Health Mission. Ministry of Health \& Family Welfare, Government of India. http://nrhm.gov.in/communitisation/ asha/about-asha.html (accessed 10 May 2015).

36 Janani Suraksha Yojana. National Health Mission. Ministry of Health \& Family Welfare, Government of India. http://nrhm.gov.in/nrhm-components/rmnch-a/ maternal-health/janani-suraksha-yojana/background.html (accessed 10 May 2015).

37 Kumar V, Misra SK, Kaushal SK, et al. A study on the effect of Janani Suraksha Yojana on antenatal registration and institutional deliveries in the Agra district of Uttar Pradesh. Indian J Public Health 2015;59:54-7.

38 Bergman NJ, Jurisoo LA. The 'kangaroo method' for treating low birth weight babies in a developing country. Trop Doct 1994;24:57-60.
39 Bang AT, Reddy HM, Deshmukh MD, et al. Neonatal and infant mortality in the ten years (1993 to 2003) of the Gadchiroli field trial: effect of home-based neonatal care. J Perinatol 2005;25(Suppl 1):S92-107.

40 Kumar V, Mohanty S, Kumar A, et al. Effect of community-based behaviour change management on neonatal mortality in Shivgarh, Uttar Pradesh, India: a cluster-randomised controlled trial. Lancet 2008;372:1151-62.

41 Bhandari N, Mazumder S, Taneja S, et al. Effect of implementation of Integrated Management of Neonatal and Childhood IIIness (IMNCI) programme on neonatal and infant mortality: cluster randomised controlled trial. BMJ 2012;344:e1634.

42 Garg S, Singh R, Grover M. Bachelor of rural health care: do we need another cadre of health practitioners for rural areas? Natl Med I India 2011;24:35-7.

43 Mullan F, Frehywot S. Non-physician clinicians in 47 sub-Saharan African countries. Lancet 2007:370:2158-63.

44 Yadav K, Jarhyan P, Gupta V, et al. Revitalizing rural health care delivery: can rural health practitioners be the answer? Indian I Community Med 2009;34:3-5.

45 DeSouza SI, Rashmi MR, Vasanthi AP, et al. Mobile phones: the next step towards healthcare delivery in rural India? PLOS ONE 2014;9:e104895.

46 Integrated Child Development Services (ICDS) Scheme. http://wcd.nic.in/icds.htm (accessed 10 May 2015).

47 Karande S, Gogtay NJ. Impact of the mid-day meal scheme in India. J Postgrad Med 2014;60:113-15.

48 Right to Education. Department of School Education and Literacy. Ministry of Human Resource Development. Government of India. http://www.mhrd.gov.in/rte (accessed 10 May 2015).

49 Mahajan H, Sharma B. Utilization of maternal and child health care services by primigravida females in urban and rural areas of India. ISRN Prev Med 2014;2014:123918.

Copyright 2015 BMJ Publishing Group. All rights reserved. For permission to reuse any of this content visit http://group.bmj.com/group/rights-licensing/permissions.

BMJ Case Report Fellows may re-use this article for personal use and teaching without any further permission.

Become a Fellow of BMJ Case Reports today and you can:

- Submit as many cases as you like

- Enjoy fast sympathetic peer review and rapid publication of accepted articles

- Access all the published articles

- Re-use any of the published material for personal use and teaching without further permission

For information on Institutional Fellowships contact consortiasales@bmjgroup.com

Visit casereports.bmj.com for more articles like this and to become a Fellow 